\title{
PENGGUNAAN SALURAN KOMUNIKASI DALAM MENJAGA SIKAP HIDUP TOLERANSI BERAGAMA DI DESA KEMA SATU KABUPATEN MINAHASA UTARA
}

\section{USING OF COMMUNICATION MEDIA TO PROTECT OF RELIGIOUS TOLERANCE BEHAVIOUR IN KEMA, NORTH MINAHASA}

\author{
Art Semuel Thomas \\ Institut Agama Kristen Negeri Manado \\ Jl. Bougenville Tateli Satu, Mandolang Kabupaten Minahasa \\ Email: artsemuethomasl@yahoo.com
}

Naskah diterima tanggal 15 oktober 2018, Naskah direvisi tanggal 23 Oktober 2018, Naskah disetujui tanggal 5 November 2018

\begin{abstract}
Abstrak
Sikap hidup toleransi merupakan suatu kebutuhan yang hakiki di dalam keberagaman kehidupan bermasyarakat dimana salah satunya diwujudnyatakan dalam bentuk toleransi beragama. Saluran komunikasi merupakan salah satu prasyarat utama dalam menciptakan sebuah perdamaian menuju kehidupan yang harmoni. Tujuan penelitian ini untuk mengetahui penggunaan saluran komunikasi dalam menjaga sikap hidup toleransi beragama di Desa Kema Satu, Kecamatan Kema Kabupaten Minahasa Utara Provinsi Sulawesi Utara. Jenis penelitian ini adalah penelitian kuantitatif dengan metode survey dan jenis data cross-sectional. Teknik pengambilan sampel adalah purposive sampling, dimana sampelnya dilakukan secara random. Sampel dalam penelitian ini adalah aparat desa, tokoh agama, dan anggota masyarakat. Hasil penelitian menunjukkan bahwa, penggunaan saluran komunikasi oleh aparat pemerintah atau instansi lain belum semuanya digunakan dengan baik untuk menyebarkan informasi tentang menjaga sikap hidup toleransi beragama. Masyarakat mengetahui informasi tersebut melalui saluran komunikasi antar pribadi (tatap muka) sebesar 96\% dan dikategorikan sangat tinggi, chatting/email sebesar $4 \%$ dan dikategorikan sangat rendah. Sedangkan untuk telephone/handphone dan teleconference belum digunakan atau $0 \%$. Pada saluran komunikasi media massa informasi tentang menjaga sikap hidup toleransi beragama diketahui oleh masyarakat melalui surat kabar sebesar $56 \%$ dan dikategorikan sedang, tabloid dan film sebesar $8 \%$ dan dikategorikan sangat rendah, televisi (TV) sebesar 96\% dan dikategorikan sangat tinggi, serta media sosial sebesar $44 \%$ dan dikategorikan rendah. Selanjutnya, penyebaran informasi tentang menjaga sikap hidup toleransi beragama melalui saluran komunikasi forum media kelompok belajar, kelompok pendengar, dan kelompencapir belum dimanfaatkan atau sebesar $0 \%$.
\end{abstract}

Kata kunci: saluran, komunikasi, toleransi beragama, sikap

\begin{abstract}
Tolerance is an essential need in the diversity of community life which is one of its manifestation in the form of religious tolerance. Communication channel is one of the main prerequisites in creating peace leading to harmonious life. The aim of the study was to identify theuse of communication channel in preserving religious tolerance in KemaSatu village Kema sub district Minahasa Utara regency North Sulawesi province. This study was a qualitative research using survey method and cross sectional data. The sampling method used was purposive sampling taken randomly. The samples were the government officials, the religious figures, and the residents. The result showed that the using of communication channel by the government officials or other institutions had not been used well to spread information about preserving the religious tolerance. The public found the information out by face to face to face as amount of $96 \%$ which was categorized very high,by chatting and email is $4 \%$ which was very low, while telephone/mobile phone and teleconference had not yet been usedwhich is $0 \%$. On the mass media communication, the information of preserving the religious tolerance was known by the public 56\% from newspaper which was categorized medium, $8 \%$ from tabloids and films which was categorized very low. The highest category was from television as amount of 96. Fromsocial media is 44\% categorized low. Furthermor, the information spreading about religious
\end{abstract}


tolerance attitude through the mass media forum, study group, listeners group, and Kelompencapir (group of listeners, readers, and viewers) had not yet been used or 0\%.

Keywords: channel, communication, religious tolerance, attitude

\section{PENDAHULUAN}

$\mathrm{M}$ anusia merupakan makhluk sosial dimana manusia membutuhkan orang lain atau manusia lain dalam hidupnya, walaupun mempunyai pikiran, akal, dan perasaan yang berbeda. Hubungan pergaulan antara manusia dengan manusia lain akan mempengaruhi kehidupannya dan dapat menimbulkan ekses positif atau negatif. Dalam upaya menghindari terjadinya ekses negatif/timbulnya persinggungan dalam kehidupan sesama manusia, maka perlunya diciptakan sikap hidup toleransi yaitu sikap atau perilaku yang saling menghormati dan menghargai semua tindakan orang lain selama tindakan tersebut sesuai aturan dan norma yang berlaku dalam masyarakat. Salah satu sikap hidup toleransi sesama manusia dapat diwujudnyatakan dalam kehidupan toleransi beragama.

Toleransi antar umat beragama ialah sikap diri kita sebagai individu atau kelompok yang dengan keyakinannya kepada Tuhan Yang Maha Esa, menghormati atau menghargai individu atau kelompok yang berbeda agama. Toleransi tidak mengizinkan perbuatan diskriminatif terhadap pemeluk agama lain. Toleransi atau kerukunan (Yewangoe, 2015: 34) terdiri atas: (a) Kerukunan Autentik dan Dinamis. Autentik artinya kerukunan itu sungguh-sungguh keluar dari hati yang tulus dan murni. Dinamis artinya kerukunan dimana orang hidup tidak sekedar hidup berdampingan (ko-eksisten) secara damai, artinya kerukunan dinamis dimana di dalamnya kelompok-kelompok yang berbeda secara proaktif, dinamis, serta kreatif terlibat dalam interaksi yang intens dan terus-menerus untuk mencari kebenaran yang lebih tinggi, untuk merumuskan kesepakatankesepakatan bersama yang lebih berkualitas. (b). Kerukunan dan kebebasan, artinya keseimbangan yang dinamis antara kerukunan dan kebebasan. Maksudnya, kerukunan itu haruslah terpancar dari kebebasan, dan bukan sebaliknya, justru mematikan atau melumpuhkannya.

Sikap hidup toleransi beragama dapat dipengaruhi oleh saluran komunikasi yang baik antara sesama manusia. Bentuk saluran komunikasi menurut Siahaan (1990: 19-22) terdiri atas: (1) Komunikasi Antar Pribadi (interpersonal communication), yaitu komunikasi yang terjalin antara dua pihak, bersifat langsung dan sering dalam bentuk percakapan (lisan atau tulisan). Pada prinsipnya, komunikasi ini berlangsung secara berhadapan muka (face to face) atau melebihi medium tertentu; (2) Komunikasi Antar Kelompok (group communication), yaitu komunikasi akan berlaku antara seorang komunikator dengan sejumlah komunikan yang berkumpul bersama. Kelompok itu bisa kecil (small group) atau besar (large group); (3) Komunikasi Massa (massa communication), (Liliweri, 1991: 36) yaitu komunikasi yang menggunakan saluran (media) dalam menghubungkan komunikator dengan komunikan secara massal, berjumlah banyak, bertempat tinggal jauh, sangat heterogen, dan menimbulkan efek-efek tertentu.

Saluran komunikasi ditandai dengan adanya intensitas komunikasi antara anggota masyarakat dimana anggota masyarakat dapat menyuarakan, menyalurkan ide-ide dan gagasan sebagai bagian dari anggota masyarakat. Saluran komunikasi yang efektif memberikan peluang untuk anggota masyarakat berkontribusi secara langsung terhadap perkembangan masyarakat, walaupun hanya sebatas ide atau gagasan. Melalui komunikasi yang efektif, maka setiap permasahan yang dihadapi masyarakat akan dapat didiskusikan dan diselesaikan secara seksama. Tanpa adanya saluran komunikasi yang efektif, maka setiap masalah yang dihadapi dapat menjadi potensi menimbulkan perpecahan antar anggota masyarakat terutama pada masyarakat yang heterogen, baik dari aspek sosial, budaya ataupun keyakinan. Saluran komunikasi yang efektif merupakan prasyarat utama atau salah satu faktor dalam menciptakan sebuah perdamaian masyarakat menuju kehidupan yang harmoni dalam sikap hidup toleransi beragama.

Sikap hidup toleransi beragama yang selama ini terbangun di desa tersebut menarik untuk ditelisik lebih dalam, dihubungkan dengan penggunaan saluran komunikasi. Penelitian ini bertujuan untuk mengetahui penggunaan saluran komunikasi dalam menjaga sikap hidup toleransi beragama. 


\section{METODE PENELITIAN}

Jenis penelitianiniadalah penelitian kuantitatif yaitu penelitian yang menggunakan asumsi-asumsi pendekatan positivis (Prasetyo dan Jannah, 2005: 53). Menurut Bungin (2010: 32) positivisme melahirkan pendekatan-pendekatan paradigma kuantitatif dalam penelitian sosial, dimana objek penelitian dilihat memiliki keberaturan yang naturalistik, empiris, dan behavioristik, dimana temuan objek penelitian harus dapat direduksi menjadi fakta yang dapat diamati, tidak terlalu mementingkan fakta sebagai makna namun mementingkan fenomena yang tampak, serta serba bebas nilai atau objektif dengan menentang habishabisan sikap-sikap subjektif. Metode penelitian ini menggunakan metode survey (Nazir, 2005: 56) yaitu penyelidikan yang diadakan untuk memperoleh fakta-fakta dari gejala-gejala yang ada dan mencari keterangan-keterangan secara faktual, baik tentang institusi sosial, ekonomi, atau politik dari suatu kelompok ataupun suatu daerah.

Jenis data dalam penelitian ini adalah crosssectional (Bungin, 2010: 44), hal tidak sama dengan penelitian longitudinal, bahwa seseorang atau kelompok, satu tahun yang akan datang mungkin ada perbedaan. Begitu pula apabila dihubungkan dengan cara pengambilan data secara terusmenerus, maka penelitian cross-sectional merupakan kompromi antara one-shot method (menembak satu kali terhadap kasus) dan longitudinal method (menembak beberapa kali terhadap kasus yang sama).

Teknik pengumpulan data yang digunakan dalam penelitian ini terdiri atas: 1) data primer (Sugiyono, 2008: 156) yaitu sumber data yang langsung memberikan data kepada pengumpul data. Data primer didapatkan melalui kegiatan: (a) Observasi yaitu cara pengambilan data dengan menggunakan mata untuk mengamati (Nazir, 2005: 175); (b) Kuesioner/Angket yaitu daftar pertanyaan yang diberikan kepada orang lain bersedia memberikan respons (responden) sesuai dengan permintaan pengguna. Tujuan penyebaran angket ialah mencari informasi yang lengkap mengenai suatu masalah dari responden tanpa merasa khawatir bila responden memberikan jawaban yang tidak sesuai dengan kenyataan dalam pengisian daftar pertanyaan (Riduwan, 2009: 38); (c) Wawancara yaitu teknik pengumpulan data apabila peneliti ingin melakukan studi pendahuluan untuk menemukan permasalahan yang harus diteliti, dan juga apabila peneliti ingin mengetahui hari-hari dari responden yang lebih mendalam dan jumlah respondennya sedikit (Sugiyono, 2008: 157); (2) data sekunder yaitu merupakan sumber yang tidak langsung memberikan data kepada pengumpul data, misalnya lewat orang lain atau lewat dokumen (Sugiyono, 2008: 156). Teknik pengumpulan data sekunder didapatkan dari Badan Pusat Statistik.

Metode pengambilan sampel dilakukan secara purposive sampling yaitu teknik sampling yang digunakan peneliti jika peneliti mempunyai pertimbangan-pertimbangan tertentu didalam pengambilan sampelnya atau penentuan sampel untuk tujuan tertentu (Riduwan, 2009: 16). Sampel dalam penelitian iniadalah aparat desa, tokoh agama, dan anggota masyarakat yang diambil secara acak/random. Kemudian metode analisis datamenggunakan Skala Guttman, (Riduwan, 2009: 30) yaitu skala yang digunakan untuk jawaban yang bersifat jelas (tegas) dan konsisten. Misalnya: yakin - tidak yakin; ya - tidak; benar - salah; positif negatif; pernah - belum pernah; setuju - tidak setuju dan lain sebagainya. Skala Guttman disamping dapat dibuat dalam bentuk pilihan ganda dan bisa dibuat dalam bentuk checklist. Jawaban responden untuk jawaban Ya (1) dan Tidak (0). Setelah dilakukan skoring kemudian pertanyaan dihitung dengan cara persentase (\%) jawaban pertanyaan dengan rumus:

$$
\mathrm{P}=\mathrm{f} / \mathrm{n} \times 100 \%
$$

\section{Dimana:}

$\mathrm{P} \quad=$ Persentase

$\mathrm{f} \quad=$ frekuensi jawaban YA

$\mathrm{n} \quad=$ (jumlah responden $\mathrm{x}$ jumlah pertanyaan)

(Bungin, 2010)

Dengan kriteria persentase yang diperoleh diterjemahkan sebagai berikut:

$86 \%-100 \%=$ sangat tinggi

$71 \%-85 \%=$ tinggi

$56 \%-70 \%=$ sedang

$41 \%-55 \%=$ rendah

$<40 \%=$ sangat rendah (Aqip, 2009)

\section{PEMBAHASAN}

\section{Profil Singkat Desa Kema Satu Kecamatan Kema} Kabupaten Minahasa Utara

Desa Kema Satu, Kabupaten Minahasa Utara, memiliki luas wilayah sebesar $7 \mathrm{~km} 2$ atau 5,79\% dari total luas wilayah Kecamatan Kema dengan jarak ke ibukota kecamatan sejauh 0,10 km dan merupakan daerah pesisir. Jumlah penduduk 
sebanyak 3.371 jiwa yang terdiri dari jumlah penduduk berjenis kelamin laki-laki sebanyak 1.692 jiwa dan perempuan sebanyak 1.679 jiwa. Jumlah penduduk pemeluk agama Kristen: 2.112 jiwa, Islam: 932 jiwa, Katolik: 314 jiwa, Hindu: 0 jiwa, Budha: 0 jiwa. Jumlah rumah ibadah adalah Masjid: 1 buah, Mushola: 1 buah, Gereja Kristen: 7 buah, Gereja Katholik: 1 buah, Pura: 0, dan Wihara: 0 (Badan Pusat Statistik Kabupaten Minahasa Utara, 2017).

\section{Penggunaan Saluran Komunikasi dalam Menjaga Sikap Hidup Toleransi Beragama}

Hasil penelitian penggunaan saluran komunikasi dalam menyebarkan informasi tentang menjaga sikap hidup tolerasi beragama di Desa Kema Satu Kabupaten Minahasa Utara tersaji pada Tabel 1.

Tabel 1. Persentase Penggunaan Saluran Komunikasi Dalam Menyebarkan Informasi tentang Menjaga Sikap Hidup Toleransi Beragama di Desa Kema Satu Kabupaten Minahasa Utara

\begin{tabular}{|c|c|c|c|}
\hline \multirow[t]{2}{*}{ No } & \multirow{2}{*}{$\begin{array}{l}\text { Saluran Komunikasi Penye- } \\
\text { baran Informasi }\end{array}$} & \multicolumn{2}{|c|}{ Jawaban (\%) } \\
\hline & & $\mathrm{Ya}$ & Tidak \\
\hline I & \multicolumn{3}{|c|}{$\begin{array}{l}\text { Saluran Komunikasi Antar Pribadi (inter- } \\
\text { personal communication) }\end{array}$} \\
\hline I. 1 & Tatap Muka & 96 & 4 \\
\hline I. 2 & Telepon/Hand Phone & 0 & 100 \\
\hline I. 3 & Chating/Email & 4 & 96 \\
\hline I. 4 & Teleconfrence & 0 & 100 \\
\hline II & \multicolumn{3}{|c|}{$\begin{array}{l}\text { Saluran Komunikasi Media Massa (mass- } \\
\text { media communication) }\end{array}$} \\
\hline II. 1 & Surat kabar & 56 & 44 \\
\hline II. 2 & Leaflet & 0 & 100 \\
\hline II. 3 & Brosur & 0 & 100 \\
\hline II. 4 & Tabloid & 8 & 92 \\
\hline II. 5 & $\mathrm{CD}$ & 0 & 100 \\
\hline II.6 & Film & 8 & 92 \\
\hline II.7 & TV & 96 & 4 \\
\hline II. 8 & Medsos & 44 & 56 \\
\hline III & \multicolumn{3}{|c|}{ Saluran Komunikasi Forum Media } \\
\hline III.1 & Kelompok Belajar & 0 & 100 \\
\hline III. 2 & Kelompok Pendengar & 0 & 100 \\
\hline III.3 & Kelompencapir & 0 & 100 \\
\hline
\end{tabular}

Sumber : Hasil Olahan Data (2018)

\section{Saluran Komunikasi Antar Pribadi (interpersonal communication) \\ Tatap Muka}

Berdasarkan data Tabel 1, responden yang menjawab "Ya" bahwa mereka menerima atau mengetahui informasi tentang menjaga sikap hidup toleransi beragama melalui saluran komunikasi antar pribadi tatap muka publik sebesar $96 \%$. Berdasarkan angka tersebut dapat dikategorikan bahwa informasi yang diterima oleh masyarakat melalui saluran komunikasi antar pribadi tatap muka publik sangat tinggi dan dapat dinyatakan:

1. Pesan yang disampaikan narasumber diterima sebagian besar anggota masyarakat.

2. Efektifnya pengaruh saluran komunikasi tatap muka dalam media penyampaian pesan kepada anggota masyarakat, sehingga dapat memberikan pemahaman atau mempengaruhi sikap masyarakat terhadap pesan yang disampaikan.

3. Adanya keseimbangan antara narasumber (komunikator) dan anggota masyarakat (komunikan) serta mempunyai kebersamaan dalam mencapai tujuan bersama terhadap informasi yang disampaikan.

4. Efektifnya kemampuan narasumber dalam memproyeksikan dirinya untuk berperan dalam menyebarkan informasi.

Ciri-ciri komunikasi publik adalah : (1) Terjadi di tempat umum (publik), misalnya : di auditorium, kelas, tempat ibadah (masjid, gereja) atau tempat lainnya yang di hadiri sejumlah besar orang, (2) Merupakan peristiwa sosial yang biasanya telah direncanakan alih-alih peristiwa relatif informal yang tidak terstruktur, (3) Terdapat agenda, (4) Beberapa orang ditunjuk untuk menjalankan fungsi-fungsi khusus, seperti memperkenalkan pembicara, dan sebagainya, (4) Acara-acara lain mungkin direncanakan sebelum atau sesudah ceramah disampaikan pembicara, (5) Memberikan penerangan,menghibur,memberikanpenghormatan, atau membujuk (https://husadaindah.wordpress. com, diakses 27/09/2018). Dalam komunikasi tatap muka didepan publik mempunyai tujuan informatif dan persuasif. Komunikasi yang bersifat informatif berusaha untuk menciptakan pemahaman yaitu memberikan penjelasan, mempertegas, mengoreksi kesalah-pahaman, mendemonstrasikan cara kerja, atau menjelaskan bagaimana terjadinya sesuatu hal. Pada komunikasi ini akan sangat menekankan pada bahan-bahan yang sifatnya memperkuat dalam bentuk contoh-contoh, ilustrasi, definisi, 
kesaksian, visualisasi, dan sejenisnya. Sedangkan komunikasi bersifat persuasif berusaha untuk mempengaruhi sikap dan perilaku. Komunikasi ini dimaksudkan untuk menguatkan sikap yang sudah ada atau mengubah keyakinan para khalayak, atau dimaksudkan agar khalayak melakukan sesuatu. Komunikasi persuasif ini akan lebih menekankan pada bahan-bahan yang menyajikan bukti-bukti, misalnya pendapat, fakta, dan himbauan psikologis. Komunikasi persuasif ini mengetengahkan sajian yang sifatnya memperkuat, memberikan ilustrasi dan menyodorkan informasi kepada khalayak (Devito, 1996:361).

Pesan yang disampaikan pada komunikasi tatap muka yaitu secara langsung dari komunikator dan langsung menerima umpan balik/feedback dari komunikan saat melakukan proses interaksi. Jika umpan balik yang disampaikan bersifat positif, maka pesan dapat diterima dengan baik oleh komunikan. Sebaliknya jika respon bersifat negatif, maka komunikator harus memperbaiki cara penyampaian pesan yang dimaksud. Pesan yang disampaikan dapat berupa suatu informasi, ajakan, ataupun gagasan. Keuntungan komunikasi tatap muka adalah meningkatkan pemahaman terhadap arti yang tersimpan.

Menurut Sendjaja (1994: 41) pada komunikasi antarpribadi, yaitu komunikasi yang berlangsung secara dialogis antara dua orang atau lebih. Karakteristik komunikasi antar pribadi yaitu : (1) Dimulai dari diri sendiri, (2) Sifatnya transaksional karena berlangsung serempak, (3) Komunikasi yang dilakukan tidak hanya mencakup aspek-aspek isi pesan yang dipertukarkan, tetapi juga meliputi hubungan antar pribadi, (4) Adanya kedekatan fisik antara pihak-pihak yang berkomunikasi, (5) Adanya saling ketergantungan antara pihak-pihak yang berkomunikasi, (6) Tidak dapat diubah maupun diulang. Maksudnya jika salah dalam pengucapan mungkin dapat minta maaf, tetapi itu bukan berarti menghapus apa yang telah diucapkan.

Pesan yang disampaikan melalui saluran komunikasi antar pribadi tatap muka publik tentang menjaga sikap hidup toleransi beragama merupakan bentuk komunikasi persuasif. Melalui komunikasi persuasif ini, narasumber berusaha mempengaruhi masyarakat dengan pesan-pesan yang dimaksud agar masyarakat tidak melakukan suatu tindakan yang negatif yang dapat merusak kerukunan beragama di desa tersebut.

Kemudian berdasarkan Tabel 1, hanya 4\% anggota masyarakat yang menjawab "tidak" yaitu tidak mengetahui informasi tentang menjaga sikap hidup toleransi beragama atau dapat dikategorikan sangat rendah, hal ini disebabkan: 1) Sebagian anggota masyarakat disibukkan dengan kegiatan mencari nafkah hidup sehari-hari sehingga kesempatan untuk mengikuti acara kegiatan kemasyarakatan rendah; 2) Sebagian anggota masyarakat mengetahui informasi tersebut melalui saluran komunikasi yang lain.

\section{Jenis Pertemuan Tatap Muka Publik}

Jumlah persentase penyebaran informasi tentang menjaga sikap hidup toleransi beragama melalui saluran komunikasi antar pribadi tatap muka publikpada setiap jenis pertemuan tersebut tersaji pada Tabel 2.

Tabel 2. Sebaran Informasi tentang Menjaga Sikap Hidup Toleransi Beragama melaluiSaluran KomunikasiAntar Pribadi Jenis Pertemuan Tatap Muka Publik

\begin{tabular}{clc}
\hline No & $\begin{array}{c}\text { Jenis PertemuanTatap Muka } \\
\text { Publik }\end{array}$ & Jumlah (\%) \\
\hline 1 & Kedukaan & 76 \\
2 & Pesta Pernikahan & 68 \\
3 & $\begin{array}{l}\text { Ibadah Keagamaan (gereja, } \\
\text { masjid, rayon,kaum bapa, }\end{array}$ & 44 \\
& kaum ibu, majelis ta'lim, \\
& remaja mesjid) & \\
4 & Sekolah & 8 \\
5 & Arisan & 4 \\
6 & PKK & 12 \\
7 & Kerja Bakti & 4 \\
8 & Tidak/Belum Tahu & 4 \\
\hline Sumber Datadiolah(2018) &
\end{tabular}

\section{Pertemuan Kedukaan}

Berdasarkan data tabel 2 di atas, bahwa informasi tentang menjaga sikap hidup toleransi beragama didapatkan oleh masyarakat melalui pertemuan kedukaan sebesar $76 \%$ dan dikategorikan tinggi. Pada pertemuan kedukaan tersebut, masyarakat yang hadir atau terkumpul dikarenakan kematian dapat terjadi setiap saat pada setiap orang, dan masyarakat juga menilai kehadiran dari setiap orang pada pertemuan sedemikian. Kalau anggota masyarakat jarang atau tidak pernah hadir pada pertemuan sedemikian, ketika terjadi sesuatu terhadap anggota masyarakat tersebut atau dalam keluarganya, maka jumlah kehadiran masyarakat pada pertemuan kedukaan yang dialami oleh 
anggota masyarakat tersebut akan sangat minim. Selain daripada itu, pada pertemuan tersebut masyarakat yang hadir secara tidak langsung diwajibkan untuk hadir walaupun tidak diundang, karena memang sudah lama menjadi tradisi yang berlaku di desa tersebut dengan tidak memandang suku, etnis atau golongan agama.

Dengan besarnya kehadiran masyarakat pada pertemuan tersebut, dimanfaatkan sebaiknya oleh aparat pemerintah desa atau tokoh agama sebagai narasumber dalam menyebarkan informasi/anjuran tentang menjaga sikap hidup toleransi beragama. Sehingga adanya korelasi antara tingginya masyarakat menerima informasi pada pertemuan tatap muka publik dengan kewajiban masyarakat hadir pada acara kedukaan tersebut. Narasumber dalam menyampaikan informasi tersebut masuk dalam susunan acara, diberikan kesempatan untuk menyebarkan informasi dan salah satu pesan yang disampaikan adalah tentang informasi toleransi beragama yang disisipkan pada informasi utama pertemuan.

Kedukaan adalah bagian pengalaman hidup yang harus dihadapi manusia, tidak bisa dipaksakan dan tidak bias diprediksi kapan akan berakhir. Namun, kedukaan dialami sebagai reaksi dari kehilangan sesuatu atau seseorang yang begitu dikasihi. Kedukaan terbesar yang dialami manusia diakibatkan oleh kematian orang yang dikasihi (http://repository.uksw. diakses 28/09/2018). Pertemuan kedukaan merupakan pertemuan yang dihadiri oleh seluruh anggota keluarga, kerabat, atau anggota masyarakat tanpa memandang suku, agama, etnis, ras, dan antar golongan yang dapat difasilitasi oleh pemerintah dan/atau agama yang dianut oleh keluarga yang berduka dalam rangka pelepasan arwah jenazah yang sudah meninggal.

\section{Pertemuan Pesta Pernikahan}

Berdasarkan data tabel 2 berikut, bahwa informasi tentang menjaga sikap hidup toleransi beragama yang didapatkan oleh masyarakat melalui pertemuan pesta pernikahan sebesar 68\% dan dikategorikan sedang. Kehadiran masyarakat pada pertemuan pesta pernikahan terbatas hal ini dipengaruhi oleh: 1) Jumlah undangan yang disebarkan kepada anggota masyarakat hanya terbatas disesuaikan dengan kemampuan ekonomi dari keluarga yang melaksanakan pertemuan pesta pernikahan, akan tetapi undangan tidak terbatas berdasarkan suku, etnis atau golongan agama; 2) Jadwal pelaksanaan pertemuan pesta pernikahan tidak ada kesesuaian waktu lowong dari para undangan.

Berdasarkan hal tersebut, persentase informasi yang diterima oleh anggota masyarakat lebih rendah dibandingkan pada pertemuan kedukaan. Pada pertemuan tersebut yang menyebarkan informasi sebagai narasumber adalah aparat pemerintah desa atau tokoh agama dimana informasi tersebut disisipkan pada informasi utama pertemuan oleh narasumber.

Pesta atau resepsi pernikahan merupakan kegiatan suatu pesta yang dihadiri oleh para undangan atau tamu undangan. Resepsi juga dapat dikatakan sebagai suatu hal yang menggambarkan keadaan pesta yang dihadiri oleh tamu-tamu tertentu. Di dalam pernikahan, repsepsi dimaknai sebagai wadah atau tempat untuk mengumumkan, bahwa di tempat tersebut sedang berlangsung atau telah terjadi pernikahan suami-istri. Resepsi di dalam pernikahan dijadikan seseorang untuk mengucapkan selamat kepada pasangan baru dan orang tuanya. Resepsi dalam pernikahan atau pun dalam suatu kagiatan tertentu seperti konferensi pers perlu pengaturan-pengaturan terlebih dahulu.

Pengaturan-pengaturan tersebut yaitu hanya memilih dan mengundang seseorang yang kemungkinan besar berminat, adanya pemberitahuan terlebih dahulu mengenai tujuan acara, tamu undangan harus dihubungi sebelum acara dilaksanakan atau dilakukan, semua tamu harus memberikan tanda tangan sebagai tanda siapa saja yang hadir (konferensi pers), tuan rumah harus diberitahu siapa saja yang diundang, pembicara dalam presepsi harus berlatih terlebih dahulu (konferensi pers), hanya hadirkan tuan rumah yang punya tujuan dan maksud yang kuat mengenai acara (konferensi pers), adanya pembatasan tuan rumah (konferensi pers) (https://id.wikipedia.org, diakses 28/09/2018).

\section{Pertemuan Ibadah Keagamaan}

Berdasarkan tabel 2, bahwa informasi tentang menjaga sikap hidup toleransi beragama didapatkan oleh masyarakat melalui pertemuan ibadah keagamaan gereja, masjid, ibadah rayon, kolom, kaum bapa, kaum ibu, remaja masjid, majelis ta'lim sebesar $44 \%$ dan dikategorikan rendah, hal ini disebabkan oleh: 1) Masih kurangnya jumlah narasumber dalam memberikan informasi melalui setiap pertemuan keagamaan; 2) Penyebaran informasi yang dilakukan oleh aparat pemerintah desa hanya terbatas pada kegiatanbesar 
keagamaan atau awal tahun; 3) Tokoh agama dalam menyebarkan informasi tersebut jumlahnya terbatas dan tokoh agama hanya menyebarkan ajaran agama sesuai yang dianutnya. Berdasarkan hal tersebut jumlah persentase anggota masyarakat yang menerima informasi tersebut di pertemuan keagamaan rendah. Kemudian untuk setiap pertemuan di ibadah keagamaan narasumber yang melakukan penyebaran informasi adalah pimpinan setiap kelompok ibadah.

\section{Pertemuan Sekolah}

Berdasarkan tabel 2, informasi atau anjuran tentang menjaga sikap hidup toleransi beragama didapatkan oleh masyarakat melalui pertemuan di sekolah sebesar $8 \%$ dan dikategorikan sangat rendah. Anggota masyarakat yang dimaksud adalah siswasiswi yang sementara menempuh studi di sekolah atau siswa-siswi yang belum lama lulus dari sekolah menengah atas. Sangat rendahnya angka persentase ini disebabkan oleh informasi ini hanya diterima terbatas pada siswa-siswi sekolah menengah atas, yang diberikan pada saat mata pelajaran yang terkait dengan agama atau pendidikan kewarganegaraan. Narasumber yang memberikan informasi tersebut adalah guru mata pelajaran disekolah tersebut.

Pertemuan di sekolah merupakan kegiatan pembelajaran melalui tatap muka dengan proses interaksi antara pendidik (guru) dan peserta didik (siswa/siswi). Proses interaksi tersebut dapat dilakukan melalui ceramah, diskusi, demonstrasi, dan tanya jawab.

\section{Pertemuan Arisan}

Berdasarkan tabel 2, informasi tentang menjaga sikap hidup toleransi beragama didapatkan oleh masyarakat melalui pertemuan arisan sebesar $4 \%$ dan dikategorikan sangat rendah, hal ini disebabkan oleh: 1) Pada kegiatan pertemuan arisan jumlah anggota masyarakat yang ikut kegiatan tersebut kurang karena tidak diwajibkan; 2) Rendahnya jumlah kelompok arisan yang terbentuk di dalam desa. Adapun narasumber yang memberikan informasi tersebut adalah aparat desa dan ketua arisan. Rendahnya masyarakat yang mendapatkan informasi tersebut berkorelasi dengan sedikitnya anggota masyarakat yang mengikuti kegiatan arisan di dalam desa.

Arisan adalah kelompok orang yang mengumpul uang secara teratur pada tiap-tiap periode tertentu. Setelah uang terkumpul, salah satu dari anggota kelompok akan keluar sebagai pemenang. Penentuan pemenang biasanya dilakukan dengan jalan pengundian, namun ada juga kelompok arisan yang menentukan pemenang dengan perjanjian. Di Indonesia, dalam budaya arisan, setiap kali salah satu anggota memenangkan uang pada pengundian, pemenang tersebut memiliki kewajiban untuk menggelar pertemuan pada periode berikutnya arisan akan diadakan (https://id.wikipedia.org, diakses 29/09/2018).

\section{Pertemuan PKK}

Berdasarkan tabel 2, informasi tentang menjaga sikap hidup toleransi beragama yang didapatkan oleh masyarakat melalui pertemuan Pemberdayaan Kesejahteraan Keluarga (PKK) sebesar $12 \%$ dan dikategorikan sangat rendah, hal ini disebabkan anggota masyarakat yang mengikuti kegiatan ini hanya terbatas pada kaum wanita. PKK merupakan wadah daripada para wanita khususnya ibu-ibu rumah tangga untuk belajar kemandirian. Pertemuan PKK merupakan salah satu wadah yang digunakan untuk menyampaikan informasi atau sosialisasi program pemerintah kepada masyarakat. Fungsi daripada pertemuan PKK (www.kompasiana.com, diakses 28/09/2018) adalah: (1) Dengan kegiatan PKK bisa untuk ajang silaturahmi antar warga; (2) Sebagai tempat untuk mendapatkan informasi yang dapat dipertanggung jawabkan mengenai kegiatan ditingkat Kalurahan maupun Kecamatan; (3) Sebagai tempat untuk belajar berorganisasi di lingkup yang kecil; (4) Ada isian baik dari warga sendiri atau mengambil dari luar mengenai kesehatan, kebersihan maupun keterampilan yang bisa menambah wawasan dan pengalaman.

Narasumber yang memberikan informasi pada pertemuan PKK adalah ketua PKK dan aparat pemerintah desa. Ketua PKK merupakan pengendali, motivator, fasilitator, pembina, dan penggerak dalam menjalankan program PKK. Fungsi kepemimpinan ketua PKK sebagai komunikator dalam organisasi salah satunya menyampaikan pesan dari seseorang, kelompok atau pemerintah kepada anggota kelompoknya atau masyarakat.

\section{Pertemuan Kerja Bakti}

Berdasarkantabel2,informasitentang menjaga sikap hidup toleransi beragama didapatkan oleh masyarakat melalui pertemuan kerja bakti sebesar $4 \%$ dan dikategorikan sangat rendah. Jumlah angka persentase yang sangat rendah terhadap informasi ini yang didapatkan masyarakat melalui kerja bakti disebabkan oleh, frekuensi kegiatan kerja bakti 
yang terjadi di dalam desa terbatas, hanya karena ada intruksi secara insidentil dari pemerintah yang diperlukan untuk membangun desa.

Kerja bakti merupakan suatu kegiatan sosial yang dilakukan secara swadaya oleh masyarakat. Kerja bakti dikoordinir oleh aparat desa dimana semua anggota masyarakat berkumpul untuk membersihkan lingkungan desa tanpa memandang tua-muda, kaya miskin, etnis, suku atau golongan agama. Pertemuan kerja bakti dapat menyatukan warga yang jarang melakukan kegiatan sosialisasi. Kerja bakti sebagai salah satu wadah berkumpulnya anggota masyarakat, maka aparat pemerintah desa memanfaatkan wadah ini sebagai tempat untuk menyampaikan informasi yang berhubungan dengan toleransi beragama.

\section{Tidak/Belum Tahu}

Berdasarkan tabel 2, adanya $4 \%$ anggota masyarakat tidak/belum mengetahui informasi tentang menjaga sikap hidup toleransi beragama melalui saluran komunikasi di setiap pertemuan tatap muka publik. Hal ini disebabkan anggota masyarakat disibukkan dengan pekerjaannya masing-masing untuk mencari nafkah hidup.

\section{Narasumber Penyebar Informasi}

Narasumber yang menyebarkan informasi tentang menjaga sikap hidup toleransi bergamamelalui saluran komunikasi antar pribadi tatap muka publik tersaji pada tabel 3 berikut:

Tabel 3. Narasumber sebagai Penyebar Informasi Menjaga Sikap Hidup Tolerasi Beragama dalam Pertemuan Tatap Muka Publik

\begin{tabular}{cll}
\hline No & Narasumber & Jumlah (\%) \\
\hline 1 & Aparat Desa & 84 \\
2 & Tokoh Agama & 64 \\
3 & Guru Agama & 12 \\
4 & Kepala Sekolah & 4 \\
5 & Ketua PKK & 4 \\
\hline Sumber & Data diolah (2018) &
\end{tabular}

\section{Aparat Desa}

Berdasarkan tabel 3, masyarakat menerima informasi tentang menjaga sikap hidup toleransi beragama melalui narasumber aparat desa sebesar $84 \%$ dan dikategorikan tinggi. Tingginya angka persentase ini disebabkan aparat desa merupakan pemerintah yang salah satunya bertanggung jawab terhadap keamanan di dalam desa. Sehingga dalam setiap pertemuan sosial kemasyarakatan aparat pemerintah diberikan kesempatan untuk menyebarkan informasi dan salah satunya tentang toleransi beragama. Aparat desa ini terdiri dari kepala desa, sekretaris desa, kepala urusan kesejahteraan rakyat, dan kepala jaga. Persentase aparat desa sebagai narasumber dalam penyebaran informasi dapat dilihat pada Tabel 4 berikut:

Tabel 4. Aparat Desa sebagai Narasumber dalam Penyebaran Informasi Menjaga Sikap Hidup Toleransi Beragama dalam Pertemuan Tatap Muka Publik

\begin{tabular}{lll}
\hline No & Narasumber & Jumlah (\%) \\
\hline 1 & Kepala Desa & 72 \\
2 & Sekretaris Desa & 16 \\
3 & Kepala Jaga & 8 \\
4 & Kepala Urusan Kesejahteraan & 4 \\
& Rakyat & \\
\hline Sumber: Data diolah (2018)
\end{tabular}

\section{Kepala Desa}

Berdasarkan tabel 4, jumlah angka persentase Kepala Desa sebagai narasumber dalam penyebaran informasi tentang menjaga sikap hidup toleransi beragama sebesar $72 \%$ dan dikategorikan tinggi. Hal ini disebabkan Kepala Desa merupakan pemimpin yang menjadi panutan dan tokoh sentral yang dihormati dalam masyarakat di tingkat desa sehingga selalu diutamakan dalam setiap pertemuan sosial kemasyarakatan yaitu masuk dalam struktur susunan acara sebagai kata sambutan kepala desa. Kata sambutan ini biasanya dilakukan oleh seorang pemimpin diawal pertemuan. Berfokus pada tugas dan fungsi salah satu aparat desa yaitu Kepala Desa adalah: (1) Kepala Desa bertugas menyelenggarakan Pemerintahan Desa, melaksanakan pembangunan, pembinaan kemasyarakatan, dan pemberdayaan masyarakat; (2)Untuk melaksanakan tugas, Kepala Desa memiliki fungsi sebagai berikut: a) Menyelenggarakan pemerintahan desa, seperti tata praja pemerintahan, penetapan peraturan di desa, pembinaan masalah pertanahan, pembinaan ketentraman dan ketertiban, melakukan upaya perlindungan masyarakat, administrasi kependudukan, dan penataan dan pengelolaan wilayah; b) Melaksanakan pembangunan sarana prasarana perdesaan;c) Pembinaankemasyarakatan, seperti pelaksanaan hak dan kewajiban masyarakat, partisipasi masyarakat, sosial budaya masyarakat, keagamaan, dan ketenagakerjaan; d) Pemberdayaan masyarakat, seperti tugas sosialisasi dan motivasi 
masyarakat di bidang budaya, ekonomi, politik, lingkungan hidup, pemberdayaan keluarga, pemuda, olahraga, dan karang taruna; e) Menjaga hubungan kemitraan dengan lembaga masyarakat dan lembaga lainnya.

\section{Sekretaris Desa}

Berdasarkan tabel 4, jumlah angka persentase Sekretaris Desa sebagai narasumber dalam penyebaran informasi tentang menjaga sikap hidup toleransi beragama sebesar 16\% dan dikategorikan sangat rendah, hal ini disebabkan Sekretaris Desa hanya sebagai unsur pembantu Kepala Desa dan memimpin sekretariat desa. Ketika Kepala Desa berhalangan hadir dalam suatu pertemuan sosial kemasyarakatan, maka selanjutnya Sekretaris Desa yang akan mewakilinya. Sangat rendahnya angka persentase tersebut berkorelasi dengan fungsi dari Sekretaris Desa sebagai salah satu unsur pembantu Kepala Desa. Tugas dari Sekretaris desa (www. academia. edu, diakses 28/09/2018) adalah: (1) Melakukan koordinasi terhadap kegiatan yang dilakukan oleh unsur teknis dan wilayah; (2) Melaksanakan pembinaan dan pelayanan teknis administrasi pemerintah desa dan kemasyarakatan; (3) Melaksanakan urusan keuangan, perlengkapan, rumah tangga desa, surat menyurat dan kearsipan; (4) Mengumpulkan, mengevaluasi dan merumuskan data dan program untuk pembinaan dan pelayanan masyarakat; (5) Menyusun laporan pemerintah desa; (6) Melaksanakan tugas lain yang diberikan oleh Kepala Desa.

\section{Kepala Jaga}

Berdasarkan tabel 4, jumlah angka persentase Kepala Jaga sebagai narasumber dalam penyebaran informasi tentang menjaga sikap hidup toleransi beragama sebesar $8 \%$ dan dikategorikan sangat rendah. Hal ini disebabkan Kepala Jaga sebagai salah satu unsur pembantu Kepala Desa. Ketika Kepala Desa atau Sekretaris Desa tidak dapat menghadiri pertemuan sosial kemasyarakatan, maka Kepala Jaga akan mewakili Kepala Desa dalam pertemuan tersebut. Pertemuan sosial kemasyarakatan tersebut diwakilkan kepada Kepala Jaga sesuai dengan lokasi domisili pertemuan tersebut. Tugas daripada seorang Kepala Jaga (Kepala Dusun) (www.academia.edu, diakses 28/09/2018) adalah: (1) Penyelenggara Pemerintahan tingkat dusun, (2) Membina kehidupan masyarakat dusun, (3) Membina perekonomian dusun, (4) Memelihara ketentraman dan ketertiban masyarakat dusun.

\section{Kepala Urusan Kesejahteraan Rakyat}

Berdasarkan tabel 4, jumlah angka persentase Kepala Jaga sebagai narasumber dalam penyebaran informasi tentang menjaga sikap hidup toleransi beragama sebesar $4 \%$ dan dikategorikan sangat rendah, hal ini disebabkan Kepala Urusan Kesejahteraan Rakyat merupakan salah satu pembantu Kepala Desa. Ketika Kepala Desa atau Sekretaris Desa tidak dapat menghadiri pertemuan sosial kemasyarakatan, maka Kepala Urusan Kesejahteraan Rakyat akan mewakili Kepala Desa dalam pertemuan tersebut. Angka persentasenya sangat rendah berkorelasi dengan tugasnya sebagai pembantu Kepala Desa. Tugas dari Kepala Urusan Kesejahteraan Rakyat (www. academia. edu, diakses 28/09/2018) adalah: (1) Melaksanakan koordinasi, pelayanan, penyuluhan dan pembinaan kehidupan masyarakat bidang kesejahteraan, sosial, keagamaan, kebudayaan dan pendidikan; (2) Mengumpulkan, mengelola dan mengevaluasi data bidang kesejahteraan, sosial,keagamaan, kebudayaan dan pendidikan; (3) Meyusun dan membuat laporan pada bidangnya serta menyampaikannya kepada Kepala Desa; (4) Melaksanakan tugas lain yang diberikan Kepala Desa.

\section{Tokoh Agama}

Berdasarkan tabel 3, masyarakat menerima informasi tentang menjaga sikap hidup toleransi beragama melalui tokoh agama sebesar $64 \%$ dan dikategorikan sedang. Tokoh agama merupakan salah satu orang yang menjadi panutan dalam kehidupan bermasyarakat di dalam desa. Tokoh agama menyebarkan informasi tentang keagamaan sesuai dengan ajaran agamanya masing-masing, akan tetapi dalam setiap pertemuan tokoh agama selalu menyisipkan informasi tentang menjaga kerukunan beragama. Penyebaran informasi tersebut dilakukan oleh tokoh-tokoh agama di setiap rumah ibadah dan di setiap pertemuan yang dilakukan di rumah anggota masyarakat yang melakukan kegiatan ibadah sesuai dengan ajaran agamanya masing-masing. Tokoh agama ini terdiri dari pendeta, imam, pastor, penatua, syamas, ustad, ketua kaum bapa, ketua kaum ibu, kepala stasi, ketua remaja masjid.

Tokoh agama adalah seorang figur atau panutan dalam masyarakat. Mempunyai kedudukan dan pengaruh besar di tengah-tengah masyarakatnya, karena memiliki keunggulan, baik dalam ilmu pengetahuan, integritas, dan lain sebagainya. Tokoh Agama pun berperan sebagai 
pemimpin masyarakat, sebagai imam dalam masalah agama dan masalah kemasyarakatan serta masalah kenegaraan dalam rangka menyukseskan program pemerintah. Tokoh Agama berperan sebagai pendorong masyarakat untuk berpartisipasi aktif dalam pembangunan, berperan untuk ikut serta mengatasi berbagai hambatan yang mengganggu jalannya pembangunan, khususnya mengatasi dampak negatif (https://kaltim2.kemenag.go.id, diakses 26/09/2018).

Peranan dan fungsi dari tokoh agama sangat penting dalam mengendalikan ketegangan sosial yang terjadi di masyarakat dalam iklim yang semakin demokratis ini.Tokoh agama berperan sangat penting dalam menciptakan atau membentuk opini publik atau pendapat umum yang sehat.Isu-isu yang menyesatkan dan kabar bohong yang tersebar bisa ditangkal masyarakat bila selalu berada dibawah bimbingan tokoh agama (http://lpmalmizan.com, diakses 26/09/2018).

\section{Guru Agama}

Berdasarkan tabel 3, masyarakat yang menerima informasi tentang tentang menjaga sikap hidup tolerasi beragama melalui guru agama sebesar $12 \%$ dan dikategorikan sangat rendah. Guru agama menyebarkan informasi tersebut melalui kegiatan pendidikan sesuai dengan mata pelajaran di sekolah kepada para siswa-siswi. Dalam membimbing siswa-siswinya terkait dengan mata pelajaran yang diampunya, guru agama menyisipkan informasi yang berhubungan dengan toleransi beragama. Guru Agama merupakan salah satu agen sosialisasi dalam menjaga kerukunan beragama karena membentuk nilai-nilai moral setiap anak didik sebagai generasi penerus bangsa.

Peran guru agama memberikan dampak positif dalam perkembangan kehidupan antarumat beragama di lingkungan masyarakat. Guru agama harus meningkatkan perannya untuk mengedukasikan nilai-nilai kerukunan antarumat beragama kepada publik (www.pikiran-rakyat.com, diakses 26/09/2018).

\section{Telepon/Handphone}

Berdasarkan data tabel 1, bahwa $0 \%$ responden tidak menerima informasi tentang menjaga sikap hidup toleransi bergama melalui saluran komunikasi antar pribadi telepone/ handphone. Hal ini disebabkan belum tersosialisasi dengan baik kegunaan saluran komunikasi tersebut dalam menyebarkan informasi tersebut. Penggunaan telepon/handphone belum digunakan oleh pemerintah desa atau instasi terkait untuk menyebarkan informasi yang berhubungan dengan menjaga sikap toleransi beragama. Penggunaan telepon/hanphone hanya sebatas komunikasi untuk informasi keperluan usaha/kerja, keluarga, dan pertemanan.

Telepon/handphone merupakan salah satu media komunikasi jarak jauh yang sudah biasa digunakan oleh manusia sekarang ini. Kemajuan teknologi saat ini dimana handphone sudah mengadopsi teknologi mutakhir yaitu sebagai smartphone. Walaupun canggih dan modern namun fungsi atau fitur standar tetap ada sama halnya seperti handphone yang masih menggunakan teknologi lama. Manfaat/kegunaan/ fungsi smartphone bagi kehidupan manusia adalah: (1) Komunikasi Antar Manusia. Smartphone adalah suatu bentuk pengembangan terbaru dari teknologi telepon nirkabel. Dengan smartphone seseorang dapat melakukan komunikasi seperti handphone biasa pada umumnya, yaitu seperti untuk telepon suara, mengirim pesan sms, pesan $\mathrm{mms}$, dan layanan data. Akan tetapi smartphone dilengkapi dengan prosesor, memori, dan perlengkapan lainnya yang lebih canggih mirip seperti teknologi yang ada pada computer; (2) Mencari Informasi/ Ilmu.Berselancar di dunia internet jauh lebih nyaman jika menggunakan smartphone daripada handphone biasa yang belum dilengkapi dengan teknologi yang canggih. Berselancar di dunia maya akan terasa lebih cepat dengan smartphone yang menggunakan koneksi internet tanpa kabel generasi terbaru seperti 3G, 3,5G, 4G, 4,5G, 5G, dan seterusnya. Ditambah lagi dengan web browser terbaru yang dapat menerjemahkan bahasa html dan bahasa permograman web serta teknologi terbaru lainnya; (3) Hiburan. Smartphone dapat menayangkan berbagai format multimedia yang ada. Media streaming online pun juga dapat dengan mudah dijalankan di smartphone yang canggih tanpa banyak kendala. Ditambah lagi dengan adanya berbagai aplikasi hiburan gratisan yang dapat diunduh secara gratis maupun berbayar menambah lengkap sarana hiburan yang ada pada smartphone; (4) Aplikasi. Pengguna smartphone dapat memasang dan menjalankan berbagai aplikasi yang tersedia di internet dan juga non internet yang sesuai dengan sistem operasi yang digunakannya. Setiap aplikasi memiliki spesifikasi minimal yang dibutuhkan agar dapat berjalan dengan lancar. Semakin canggih dan baru suatu gadget smartphone yang digunakan, maka pada umumnya 
semakin banyak aplikasi yang bisa dijalankan; (5) Penyimpanan Data. Kapasitas memori smartphone yang besar bisa berfungsi sebagai media penyimpanan data file. Seperti halnya USB flashdisk, USB external drive dan multimedia card, handphone yang canggih pun dapat dipergunakan untuk meletakkan berbagai file sesuai dengan kapasitas yang ada pada smartphone. Smartphone yang diberi kartu memory tambahan akan mampu menampung data lebih besar; (6) Gaya. Ada banyak orang yang menggunakan handphone smartphone untuk menunjang penampilan sehari-hari. Orang yang memiliki gengsi yang tinggi akan berusaha sekuat tenaga untuk menggunakan smartphone yang dipandang orang keren dan canggih; (7) Penunjuk Arah. Salah satu fungsi penting dari smartphone adalah untuk mendapatkan informasi arah mata angin, arah kiblat, dan lain sebagainya. Smartphone yang memiliki fasilitas GPS dapat menunjukkan arah mata angin seperti layaknya kompas sungguhan. Selain itu dengan dipadukan layanan jejaring sosial maka dapat menjadi sesuatu yang sangat menarik dan dibutuhkan (www. organisasi.org, diakses 28/09/2018).

\section{Chating atau Email}

Berdasarkan data tabel 1, responden yang menjawab "ya" bahwa mereka menerima informasi tentang menjaga sikap hidup toleransi beragama melalui saluran komunikasi chating atau email sebesar $4 \%$ dan dikategorikan sangat rendah. Rendahnya angka jumlah persentase ini disebabkan masyarakat yang menggunakan saluran komunikasi chating atau email masih terbatas pada para siswasiswi sekolah menengah atas. Hal disebabkan di sekolah sudah diajarkan tentang pengoperasian internet untuk berkomunikasi. Para siswa-siswi bertukar informasi tentang toleransi beragama melalui chating atau email dan juga mengetahui informasi lebih melalui browsing di internet. Dengan adanya internet dan kemauan siswa-siswi yang tinggi mencari informasi/pengetahuan yang lebih dari berbagai sumber melalui browsing dan searching, setidaknya memberikan kelancaran belajar siswa-siswi dan guru untuk saling mendukung berfikir kreatif dan kritis. Kehadiran internet telah merubah pola hidup serta aktivitas manusia setiap hari.Internet telah memperluas jangkauan informasi dengan mudah, cepat, dan berbiaya murah sampai ke pelosok desa dan seakan dunia tidak bejarak lagi.

Chatting adalah aktivitas berkomunikasi yang dilakukan oleh dua orang atau lebih dengan memanfaatkan aplikasi chatting dan jaringan internet. Aplikasi chatting saat ini sudah sangat maju. Tidak hanya mengirim pesan teks saja, aktivitas chatting sekarang ini juga bisa mengirimkan emoticon, pesan suara, bahkan video. Beberapa contoh aplikasi chatting yang sering digunakan oleh masyarakat diantaranya: Whatsapp (WA), Blackberry Messenger (BBM), Facebook Messenger, Yahoo Messenger (YM), Line, Google Hangout, Google Allo, Talk, dan lain sebagainya. Secara umum, chatting memiliki beberapa fungsi diantaranya: (1) Sebagai sarana berkomunikasi yang paling mudah, cepat dan efisien; (2) Sebagai sarana untuk saling berkonsultasi lebih mudah; (3) Alat untuk menjalin hubungan dengan orang lain; (4) Bisa digunakan untuk berkumpul pada suatu grup atau multiple chat (www.maxmanroe.com, diakses 28/09/2018).

Fungsi Email adalah sebagai sarana untuk mengirimkan atau menerima surat melalui jalur komputer dan internet. Data yang bisa dilampirkan dalam email tersebut berupa data digital diantaranya: dokumen, musik, video dan gambar, software, dan data digital lainnya. Jenisjenis layanan email adalah: (1) POP Mail. Email jenis ini sama dengan email yang anda terima dari Internet Service Provider anda (bagi anda yang connect internet dari rumah atau kantor).; (2) Web Based Email. Email jenis ini merupakan email yang ditawarkan berbagai situs seperti Gmail, Yahoo, Hotmail dan lain-lain. (3) Email Forwarding. Fasilitas yang memungkinkan pengalihan suatu e-mail ke alamat e-mail lainnya, dengan kata lain mail server yang melayani e-mail forwarding hanya bertindak sebagai perantara. Manfaat email adalah: (1) Dapat menghubungkan kita dengan siapa saja yang terhubung di internet di seluruh dunia dengan biaya pulsa local; (2) Dengan e-mail, data dikirim secara elektronik sehingga sampai tujuan dengan sangat cepat; (3) Dapat mengirim kepada lebih dari satu orang pada saat bersamaan; (4) Memudahkan komunikasi dengan orang yang ada di seluruh dunia. (www.fungsiklopedia.com, diakses 28/09/2018).

\section{Teleconference}

Berdasarkan data tabel 1, bahwa $0 \%$ responden tidak mendapatkan informasi tentang menjaga sikap hidup toleransi beragama melalui saluran komunikasi tatap muka teleconference.Hal ini disebabkan penggunaan saluran komunikasi teleconference belum sepenuhnya diketahui oleh masyarakat. 
Teleconference dalam bidang telekomunikasi adalah jenis pertemuan yang memiliki basis elektronika yang dilaksanakan secara live atau langsung yang dilakukan oleh minimal dua orang dan juga lebih mesin maupun manusia yang saling berkomunikasi dan dihubungkan dengan menggunakan sebuah sistem telekomunikasi yang rata-rata menggunakan saluran telepon. Pemakaian dari teleconference mempunyai sejumlah kelebihan dari sisi efektivitas waktu dan biaya. Teleconference bisa berbentuk teleconference video maupun teleconference audio. (a) Teleconference Audio adalah salah satu jenis percakapan atau teleconference yang dilakukan oleh beberapa orang yang berupa percakapan secara interaktif di dalamnya. Dengan adanya model audio konferensi tersebut maka setiap orang bisa berbicara dan tentunya bisa didengar oleh orang lain yang berada pada jaringan telekonferensi audio tersebut. (b) Teleconference Video dimana para partisipan yang tergabung pada teleconference video tersebut bisa saling melihat video maupun gambar serta bisa pula mendengar dari suara mereka masing-masing. Gambar-gambaryang ada pada teleconference video bisa dilihat melalui monitor atau layar sementara itu suara suara yang bisa didengar berasal dari speaker yang terpasang. Teleconference audio hanya membutuhkan mikrofon, sementara teleconference video membutuhkan kamera(https://inanesia. com,diakses 27 September 2018).

\section{Saluran Komunikasi Media Massa (mass-media communication) \\ Surat Kabar}

Berdasarkan Tabel 1, responden yang menjawab "Ya" bahwa mereka menerima informasi tentang menjaga sikap hidup toleransi beragama melalui saluran komunikasi media massa surat kabar sebesar $56 \%$ dan dikategorikan sedang. Anggota masyarakat mendapatkan informasi tersebut melalui surat kabar karena :

1. Anggota masyarakat membeli sendiri surat kabar tercetak tersebut dengan harga jual Rp.2000 s/d Rp.5000/eksemplar. Pembelian dilakukan secara eceran atau berlanggaran per bulan.

2. Anggota masyarakat meminjam surat kabar dari anggota masyarakat lain yang membeli.

Surat kabar tercetak yang beredar di tengah-tengah masyarakat adalah Manado Post, Komentar, dan Tribun Manado. Dengan kemudahan mendapatkan surat kabar tercetak tersebut, penyebaran informasi terkait dengan sikap hidup toleransi beragama akan dengan mudah diterima oleh masyarakat luas.Surat kabar merupakan produk jurnalis. Menurut Effendy (2003: 93-94)fungsi-fungsi surat kabar terdiri dari : (1) Fungsi Menyiarkan Informasi, yaitu fungsi surat kabar pertama dan utama. Khalayak pembaca berlangganan atau membeli surat kabar karena memerlukan informasi mengenai berbagai hal di bumi ini : mengenai peristiwa yang terjadi, gagasan atau pikiran orang lain, apa yang dilakukan orang lain, apa yang dikatakan orang lain, dan sebagainya. (2) Fungsi Mendidik, yaitu sebagai sarana pendidikan massa (mass education), surat kabar memuat tulisan-tulisan yang mengandung pengetahuan, sehingga khalayak pembaca bertambah pengetahuannya. Fungsi mendidik ini bias secara implisit dalam bentuk berita, dapat juga secara eksplisit dalam bentuk artikel atau tajuk rencana.Kadang-kadang cerita bersambung atau berita bergambar juga mengandung aspek pendidikan. (3) Fungsi Menghibur, yaitu hal-hal yang bersifat hiburan sering dimuat surat kabar untuk mengimbangi berita-berita berat (hard news) dan artikel-artikel yang berbobot. Isi surat kabar bersifat hiburan bias berbentuk cerita pendek, cerita bersambung, cerita bergambar, teka-teki silang, pojok, karikatur, tidak jarang juga berita yang mengandung minat insani (human interest), dan kadang-kadang tajuk rencana. Maksud pemuatan isi yang mengandung hiburan, semata-mata untuk melemaskan ketegangan pikiran setelah pembaca dihidangi berita dan artikel-artikel yang beratberat. (4) Fungsi Mempengaruhi, yaitu fungsi yang menyebabkan surat kabar memegang peranan penting dalam kehidupan masyarakat. Surat kabar yang ditakuti adalah surat kabar yang independent, yang bebas menyatakan pendapat, bebas melakukan social kontrol. Fungsi mempengaruhi surat kabar secara implisit terdapat pada berita, sedang secara eksplisit terdapat pada tajuk rencana dan artikel.

\section{Leaflet, Brosur, dan CD}

Berdasarkan Tabel 1, bahwa 0\% responden tidak menerima informasi tentang menjaga sikap hidup toleransi beragama melalui saluran komunikasi media massa leaflet, brosur, dan cd. Hal ini disebabkan pemerintah atau instansi lain belum menggunakan saluran komunikasi tersebut dalam menyebarkan informasi terkait toleransi beragama.

Leaflet adalah lembaran kertas berukuran kecilmengandung pesan tercetak untuk disebarkan 
kepada umum sebagai informasi mengenai suatu hal atau peristiwa. Leaflet digunakan untuk memberikan keterangan singkat tentang suatu masalah (https://feripadri.files.wordpress.com, diakses 27 September 2018).

Brosur adalah buku yang diterbitkan secara tidak berkala yang dapat terdiri dari satu hingga sejumlah kecilhalaman, tidak terkait dengan terbitan lain, dan selesai dalam sekali terbit. Halamannya sering dijadikan satu (antara lain dengan stapler, benang, atau kawat), biasanya memiliki sampul, tetapi tidak menggunakan jilid keras (https:// id.wikipedia.org., diakses 27 September 2018)

$\mathrm{CD}$ atau compact disc adalah sebuah piringan bundar yang terbuat dari logam atau plastik berlapis bahan yang dapat dialiri listrik, sehingga bersifat magnet.CD juga menyimpan data. Data direkam di atasnya, kemudian dibaca dari disk dengan menggunakan kumparan pengonduksi yang dinamakan head (https://endino.wordpress.com., diakses 27 September 2018).

\section{Tabloid}

Berdasarkan Tabel 1, responden yang menjawab "Ya" bahwa mereka menerima informasi tentang menjaga sikap hidup toleransi beragama melalui saluran komunikasi massatabloidsebesar 8\% dan dikategorikan sangat rendah. Hal ini disebabkan saluran komunikasi media massamelalui tabloid peredarannya ditengah-tengah masyarakat sangat rendah. Terbitan tabloid hanya sekali/minggu dan terbatas anggota masyarakat yang membelinya karena untuk membeli tabloid tersebut harus datang ke ibukota propinsi yaitu kota Manado atau ibukota kabupaten yaitu Airmadidi.

Tabloid adalah istilah suatu format surat kabar yang lebih kecil dari ukuran standar koran harian. Istilah ini biasanya dikaitkan dengan penerbitan surat kabar reguler non harian (bisa mingguan, dwimingguan, dan sebagainya), yang terfokus pada hal-hal yang lebih "tidak serius", terutama masalah pesohor, olahraga, kriminalitas, dan lainlain (https://id.wikipedia.org., diakses 27 September 2018).

\section{Film}

Berdasarkan Tabel 1, responden yang menjawab "Ya" bahwa mereka menerima informasi tentang menjaga sikap hidup toleransi beragama melalui saluran komunikasi massafilm sebesar 8\% dan dikategorikan sangat rendah.Hal ini disebabkan penggunaan film dalam menyebarkan informasi terkait dengan toleransi beragama yang berlaku dalam masyarakat terbatas.Anggota masyarakat menerima informasi melalui film hanya dalam bentuk hiburan.

Film merupakan sebuah karya seni berupa rangkaian gambar hidup yang diputar sehingga menghasilkan sebuah ilusi gambar bergerak yang disajikan sebagai bentuk hiburan.Ilusi dari rangkaian gambar tersebut menghasilkan gerakan kontinyu berupa video.Film juga dapat diartikan sebagai fenomena sosial, psikologi, dan estetika yang kompleks yang merupakan dokumen yang terdiri dari cerita dan gambar yang diiringi katakata dan musik. Sehingga film merupakan produksi yang multi dimensional dan kompleks (http:// forum.teropong.id., diakses 27 September 2018).

\section{Televisi (TV)}

Berdasarkan Tabel 1, responden yang menjawab "Ya" bahwa mereka menerima informasi tentang menjaga sikap hidup toleransi beragama melalui saluran komunikasi massatelevisi sebesar 96\% dan dikategorikan sangat tinggi.Hal ini disebabkan kepemilikan pesawat televisi di tengahtengah masyarakat hampir merata, sehingga informasi terkait toleransi beragamaakan dengan mudah didapatkan masyarakat.Televisi menjadi salah satu saluran komunikasi yang gratis atau murah untuk menyampaikan informasi yang penting kepada setiap orang.Selain itu anggota masyarakat untuk dapat memiliki pesawat televisi disetiap keluarga masih tergolong mudah karena harga terendah masih terjangkau untuk dibeli dan tersedia dipertokoan.

Televisi adalah sebuah media telekomunikasi terkenal yang berfungsi sebagai penerima siaran gambar bergerak beserta suara, baik itu yang monokrom (hitam-putih) maupun berwarna. Televisi dapat diartikan sebagai alat komunikasi jarak jauh yang menggunakan media visual/ penglihatan (https://id.wikipedia.org., diakses 27 September 2018).

\section{Media Sosial}

Berdasarkan Tabel 1, responden yang menjawab "Ya" bahwa mereka menerima informasi tentang menjaga sikap hidup toleransi beragama melalui saluran komunikasi massamedia sosial sebesar $44 \%$ dan dikategorikan rendah.Halini terjadi karena kepemilikan handphone ataupun laptop/ computer di anggota masyarakat sudah cukup banyak.Dengan adanya internet lebih memudahkan orang untuk mendapatkan informasi yang mudah dengan harga yang terjangkau.Pengguna media 
sosial adalah anggota masyarakat yang sudah melek teknologi. Media sosial ini antara lain facebook, twiter, instagram, bbm (blackberry messenger), dan sms (short message service).

Media sosial merupakan media online yang mendukung adanya interaksi sosial. Sosial media atau media sosial menggunakan teknologi berbasis web yang mengubah suatu komunikasi ke dalam dialog interaktif. Menurut Antony Mayfield (2008) pengertian media sosial adalah media yang penggunanya mudah berpartisipasi, berbagai dan menciptakan peran, khususnya blog, jejaring sosial, wiki/ensiklopedia online, forum-forum maya, termasuk virtual worlds (dengan avatar/karakter 3D) (http://www.artikelsiana.com., diakses 27 September 2018).

\section{Saluran Komunikasi Forum Media Kelompok Belajar, Kelompok Pendengar, dan Kelompencapir}

Berdasarkan Tabel 1, bahwa 0\% responden tidak menerima informasi tentang menjaga sikap hidup toleransi beragama melalui saluran komunikasi forum media kelompok belajar, kelompok pendengar, dan kelompencapir. Hal ini disebabkan belum membudayanya saluran komunikasi tersebut sehingga pemerintah atau instansi lainbelum memanfaatkan untuk menyebarkan informasi terkait toleransi beragama.

Kelompok belajar memiliki banyak manfaat di dalamnya, bagaimana menjadi seorang organisator, karenakelompok belajar adalah miniatur organisasi yang di dalamnya terdapat berbagai fungsi tidak hanya menyelesaikan tugas semata. Fungsi tersebut adalah kepemimpinan, manajemen waktu, rela berkorban, solidaritas, dan public speaking (https:// www.kompasiana.com., diakses 27 September 2018).Kelompok pendengaradalah kumpulan orang yang mendengar dan mendiskusikan siaran radio pedesaan atau pita rekaman, yang bersifat penyuluhan, terutama untuk masyarakat pedesaan (https://id.wiktionary.org., diakses 28 September 2018). Kelompencapir, yang merupakan singkatan dari Kelompok Pendengar, Pembaca, dan Pemirsa, adalah kegiatan pertemuan untuk petani dan nelayan di Indonesia yang dicetuskan pada masa pemerintahan Presiden Suharto. Kegiatan ini mengikutkan petani-petani berprestasi dari berbagai daerah. Mereka diadu kepintaran dan pengetahuannya seputar pertanian, antara lain soal cara bertanam yang baik dan pengetahuan tentang pupuk dengan model mirip cerdas cermat. (https:// id.wikipedia.org., diakses 28 September 2018).

\section{PENUTUP}

Berdasarkan hasil penelitianbahwa saluran komunikasi mempunyai peran yang sangat penting dalam menjaga sikap hidup toleransi beragama. Peranan saluran komunikasi tersebut bervariasi berdasarkan kategori yaitu: 1) Saluran Komunikasi Antar Pribadi (interpersonal communication); Tatap Muka sebesar 96\% dengan kategori sangat tinggi; Chatting/email sebesar $4 \%$ dengan kategori sangat rendah; Telephone/handphone dan teleconference sebesar 0\%; 2) Saluran Komunikasi Media Massa (mass-media communication); Surat Kabar sebesar 56\% dengan kategori sedang; Televisi (TV) sebesar 96\% dengan kategori sangat tinggi; Media Sosial (medsos) sebesar 44\% dengan kategori rendah; Tabloid sebesar $8 \%$ dengan kategori sangat rendah; Film sebesar 8\% dengan kategori sangat rendah; Leaflet sebesar 0\%; Brosur sebesar 0\%; CD (compact disc) sebesar 0\%; 3) Saluran Komunikasi Forum Media; Kelompok Belajar sebesar 0\%; Kelompok Pendengar sebesar 0\%; Kelompencapir sebesar 0\%

Penyebaran informasi tentang sikap menjaga sikap hidup toleransi beragama melalui saluran komunikasi antar pribadi jenis pertemuan tatap muka publik adalah : pertemuan kedukaan sebesar $76 \%$ dikategorikan tinggi, pesta pernikahan sebesar $68 \%$ dikategorikan sedang, ibadah keagamaan (gereja, masjid, rayon,kaum bapa, kaum ibu, majelis ta'lim, remaja masjid) sebesar $44 \%$ dikategorikan rendah, di sekolah sebesar $8 \%$ dikategorikan sangat rendah, arisan sebesar $4 \%$ dikategorikan sangat rendah, PKK sebesar $12 \%$ dikategorikan sangat rendah, kerja bakti sebesar $4 \%$ dikategorikan sangat rendah. Selanjutnya ada $4 \%$ anggota masyarakat yang tidak atau belum mengetahui informasi tentang menjaga sikap hidup toleransi beragama melalui beberapa jenis pertemuan tatap muka. Kemudian narasumber yang menyebarkan informasi tekait toleransi beragama adalah aparat desa sebesar $84 \%$ dikategorikan tinggi, tokoh agama sebesar 64\% dikategorikan sedang, guru agama sebesar 12\% dikategorikan sangat rendah, kepala sekolah sebesar 4\% dikategorikan sangat rendah, dan ketua PKK sebesar 4\% dikategorikan sangat rendah.

\section{UCAPAN TERIMA KASIH}

Terlaksananyapenelitian ini tidak terlepas dari dukungan berbagai pihak. Penulis sampaikan terima kasih kepada pemerintah, tokoh, dan masyarakat Desa Kema Satu Kecamatan Kema Kabupaten Minahasa Utara Provinsi Sulawesi Utara beserta Badan Pusat Statistik Provinsi Sulawesi Utara 
atas dukungannya dalam memperoleh data primer dan sekunder untuk penelitian ini. Selanjutnya disampaikan terima kasih atas saran dan masukan yang diberikan oleh tim redaksi Jurnal Al Qalam sampai pemuatan tulisan ini.

\section{DAFTAR PUSTAKA}

Aqip, Z. 2009. Penelitian Tindakan Kelas Untuk Guru SD, $S L B$, dan TK. Bandung: Yrama Widya.

Badan Pusat Statistik Kabupaten Minahasa Utara. 2017. Kecamatan Kema Dalam Angka. BPS Kabupaten Minahasa Utara

Bungin, B. 2010.Metode Penelitian Kuantitatif. Jakarta: Prenada Media Group.

Bungin, H.M. B.2010.Metode Penelitian Kuantitatif Komunikasi, Ekonomi, dan Kebijakan Publik Serta

Ilmu-Imu Sosial Lainnya. Jakarta:Kencana Prenada Media Group.

DeVito, J.A. 1996. Komunikasi Antarmanusia - Kuliah Dasar (terjemahan). Jakarta: Professional Books. Effendy, O.U. 2003. Ilmu, Teori, dan Filsafat Komunikasi. Bandung:Citra Aditya Bakti.

https://soyomakmur.blogspot.com/2017/09/tugasdan-fungsi-kepala-desa-dan.html, diakses 26 September 2018.

https://kaltim2.kemenag.go.id/berita/224946/perantokoh-agama-dalam-pembinaan-umat-dalam membangun-bangsa, diakses 26 september 2018.

http://lpmalmizan.com/2018/03/01/peranan-tokohagama-dalam-meningkatkan-partisipasi-politikmasyarakat/, diakses 26 September 2018.

h t t p : / / w w w.pikiran-rakyat.com/ pendidikan/2010/12/18/130064/didintingkatkan-peran-guru-agama, diakses 26 September 2018.

https://inanesia.com/apa-yang-dimaksud-denganteleconference/, diakses 27 September 2018).

https://feripadri.files.wordpress.com/2011/11/leaflets2. pdf, diakses 27 September 2018.

https://id.wikipedia.org/wiki/Brosur, diakses 27 September 2018.

https://endino.wordpress.com/tag/apa-itu-cd/, diakses 27 September 2018.

https://id.wikipedia.org/wiki/Tabloid, diakses 27 September 2018.

http://forum.teropong.id/2017/08/17/pengertian-filmunsur-unsur-jenis-jenis-dan-fungsi-film/, diakses 27 September 2018.

https://id.wikipedia.org/wiki/Televisi, diakses 27 September 2018. http://www.artikelsiana.com/2017/09/pengertianmedia-sosial-fungsi.html, diakses 27 September 2018.

https://husadaindah.wordpress.com/2012/02/15/ pengertian-komunikasi-publik/, diakses 27 September 2018.

https://www.kompasiana.com/lilinrofiqotulilmi/5a9aacb 5ab12ae69a23dd343/belajar-organisasi-melaluibelajar-kelompok., diakses 27 September 2018.

https://id.wiktionary.org/wiki/kelompok_pendengar, diakses 28 September 2018.

https://id.wikipedia.org/wiki/Kelompencapir, diakses 28 September 2018.

h t t p s : / / w w w. ko m pas i a n a.co m / sarie/552bf9386ea8345d088b4568/kegiatan-pkkadalah-ajang-bergosip, diakses 28 September 2018

http://www.academia.edu/10188573/TUGAS_POKOK_ DAN_FUNGSI_PERANGKAT_DESA, diakses 28 September 2018

http://www.organisasi.org/1970/01/kegunaan-fungsimanfaat-handphone-smartphone-bagi-manusia. html\#.W79cI9czbIU, diakses 28 September 2018

https://www.maxmanroe.com/vid/teknologi/pengertianchatting.html, diakses 28 September 2018.

http://www.fungsiklopedia.com/fungsi-email/, diakses 28 September 2018.

h t t p : / / r e p o s i t o ry.uks w. e d u / bitstream/123456789/13356/1/T2_752016016_ BAB $\% 20 \% 20 I I . p d f$, diakses

28 September 2018

https://id.wikipedia.org/wiki/Resepsi, diakses 28 September 2018

https://id.wikipedia.org/wiki/Arisan, diakses 29 September 2018

Liliweri, A. 1991.Memahami Peran Komunikasi Massa Dalam Masyarakat.Bandung:PT.Citra Aditya

Bakti.

Nazir, M. 2005.Metode Penelitian. Bogor:Ghalia Indonesia.

Prasetyo, B dan Jannah,L.M. 2005.Metode Penelitian Kuantitatif- Teori dan Aplikasi. Jakarta:

RajaGrafindo Persada.

Riduwan.2009.Pengantar Statistika Sosial. Bandung:Alfabeta.

Sendjaja, D.S. 1994.Teori Komunikasi. Jakarta: Universitas Terbuka Departemen Pendidikan Dan Kebudayaan RI

Siahaan, S.M. 1990. Komunikasi - Pemahaman dan Penerapannya. Jakarta:BPK Gunung Mulia.

Sugiyono. 2008. Metode Penelitian Administrasi dilengkapidengan Metode R\&D.Bandung:Alfabeta.

Yewangoe, A.A. 2015.Agama dan Kerukunan.Jakarta:BPK Gunung Mulia. 